\title{
Cytotoxicity Evaluation of Self Adhesive Composite Resin Cements by Dentin Barrier Test on 3D Pulp Cells
}

Hayriye Esra Ulker ${ }^{a}$

Abdulkadir Sengun ${ }^{b}$

\section{ABSTRACT}

Objectives: The aim of this study was to evaluate the effects of five self-etch dental composite resin cements on the cell viability of bovine dental papilla-derived cells.

Methods: The cytotoxicity of composite resin cements (Rely X Unicem Clicker, 3M ESPE; MaxCem; KERR, Panavia F 2.0; Kuraray, BisCem; Bisco and Bistite II DC; Tokuyamal was analyzed in a dentin barrier test device using three-dimensional (3D) pulp cell cultures. A commercially available cell culture perfusion chamber was separated into two compartments by $500 \mu \mathrm{m}$ dentin disc. The three dimensional cultures placed on a dentin disk held in place by a special biocompatible stainless-steel holder. Test materials were introduced into the upper compartment in direct contact with the cavity side of the dentin disks according to the manufacturer's instructions. Subsequently, the pulpal part of the perfusion chamber containing the cell cultures was perfused with medium ( $2 \mathrm{ml} / \mathrm{h}$ ). After an exposure period of $24 \mathrm{~h}$, the cell survival was determined by the MTT assay. Statistical analyses were performed using the Mann-Whitney U-test.

Results: In dentin barrier test, cell survival was similar with Maxcem and negative control group ( $P>$.05), and all other tested materials were cytotoxic for the three dimensional cell cultures (P>.05).

Conclusions: The significance of composite resin cements is being more important in dentistry. The cytotoxic potencies demonstrated by these materials might be of clinical relevance. Some composite resin cements include biologically active ingredients and may modify pulp cell metabolism when the materials are used in deep cavities or directly contact pulp tissue. (Eur J Dent 2009;3:120126)

Key words: Resin cement; Cytotoxicity; Dentin barrier test; Three dimensional cultures.

DDS, PhD, Research Assistant, Selcuk University, Faculty of Dentistry, Department of Conservative Dentistry, Konya, Turkey.

b DDS, PhD, Professor, Selcuk University, Faculty of Dentistry, Department of Conservative Dentistry, Konya, Turkey.

- Corresponding author: Dr. H. Esra Ulker Selcuk Universitesi, Dis Hekimligi Fakultesi, Dis Hastalıkları ve Tedavisi AD. Kampus, 42090, Konya, Turkey.

Phone: +90 3322231243 Fax: +90 3322410062

E-mail: esrabotsalidselcuk.edu.tr

\section{INTRODUCTION}

Resin cements are gaining popularity in the dental profession for a number of reasons. The vast majority of non-metallic restorations, which are also utilized more at the present time than before, can be cemented only with resin cements. These restorations include ceramic and resin composite inlays and onlays as well as ceramic crowns and porcelain veneers. ${ }^{1}$ An ideal dental luting cement should be biocompatible, have little interaction with body tissues and fluids, ${ }^{2}$ be 
nontoxic, and have low allergic potential. ${ }^{3}$

It has been long demonstrated that different components of resinous materials can be released in an adjacent aqueous phase. ${ }^{4,5}$ In this way, when applied to a wet surface, such as dentin, uncured free monomers released from resin-based materials may diffuse across dentinal tubules to reach the pulpal space. ${ }^{6}$ Several investigations have shown that released monomers cause chemical damage to cultured cells. ${ }^{7,8}$ In addition, many in vivo studies have shown that uncured resin components which reach the pulpal space cause inflammatory response and tissue disorganization. ${ }^{9,10}$

Dimethacrylate monomers are widely used in dentistry and the most widely used monomers for the preparation of resin cements are crosslinking dimethacrylates like bisphenol A glycol dimethacrylate (Bis-GMA), triethylene glycol dimethacrylate (TEGDMA), urethane dimethacrylate (UDMA), and bisphenol A ethoxylated dimethacrylate (Bis-EMA). Usually, mixtures of these monomers are used.11,12 Acrylates and mainly methacrylates were found to cause cytotoxic effects. Evaluation of the cytotoxicity of acrylates and methacrylates that had been used in dental resin materials showed a relationship between their structure and the degree of cytotoxicity. ${ }^{12}$ TEGDMA, and mainly BisGMA and UDMA, are highly cytotoxic. ${ }^{12-15}$

Many in vitro studies have shown that the polymerization reaction that produces the crosslinked polymer matrix from the dimethacrylate resin monomer is never complete and adverse reactions are due to the release of nonpolymerized monomers such as TEGDMA or 2-hydroxy-ethylmethacrylate (HEMA). Unbound free monomers seem to be directly responsible for the cytotoxicity of resin composites on pulp and gingival cells, and they are probably also implicated in the allergic potential of the material. ${ }^{16,17}$

The elution of unpolymerized resin components becomes significant when these materials diffuse across the permeable hybrid layer and dentinal tubules to reach the pulpal space ${ }^{4}$ from a fresh cavity preparation and are of concentrations high enough to produce a biological effect upon the dental pulp. It is evident from previous work that certain precursor components of resins are cytotoxic for fibroblastic cells in culture, ${ }^{18}$ and thus could contribute to tissue injury of the dental pulp following restorative procedures. ${ }^{19}$ In this specific situation, the odontoblasts that are underlying the circumpulpal dentin are the first cell line affected by the residual components leached from the dental materials used for cavity restoration. For this reason, odontoblasts are the appropriate as a target cells to evaluate the in vitro side effects of dental restorative materials. ${ }^{20}$ In this connection, adequate contact between cells and test material is crucial to cell cytotoxicity testing. To simulate the in vivo situation for dental filling materials, in vitro pulp chambers have been designed, introducing dentin as a barrier between test materials and target cells. Schmalz et $a^{21}$ described an in vitro dentin barrier test system, which is mainly based on commercially available components, thus fulfilling a basic requirement for standardized testing techniques. An additional advantage of this artificial pulp chamber was thought to be the possibility of perfusing the pulpal part with nutrition medium, thus simulating in vivo pulpal blood flow. The objective of the present study was to evaluate the cytotoxic effects of five selfetch dental composite resin cements by a dentin barrier test device using the three-dimensional cultures of transformed pulp-derived cells to simulate three-dimensional structure of the dental pulp tissue.

\section{MATERIALS AND METHODS}

Cell culture

Bovine dental papilla-derived cells, ${ }^{22}$ derived from calf dental papilla were maintained in growth medium (Minimum Essential Medium Alpha, Gibco Invitrogen, Germanyl supplemented with $20 \%$ fetal bovine serum (FBS) (Biochrom AG, Berlin, Germany), $150 \mathrm{lU} / \mathrm{ml}$ penicillin, $150 \mathrm{mg} /$ $\mathrm{ml}$ streptomycin (Biological Industries, Israel) and $0.1 \mathrm{mg} / \mathrm{ml}$ geneticin (Biological Industries, Israell in a humidified atmosphere at $37^{\circ} \mathrm{C}, 5 \%$ $\mathrm{CO}_{2}$. For all experiments, cells within passages 19 to 21 were used.

Preparation of three-dimensional cultures

Polyamide meshes $10.5 \mathrm{~cm}^{2}$; Reichelt Chemietechnik, Germanyl were immersed in $0.1 \mathrm{M}$ acetic acid for $30 \mathrm{~min}$, washed three times with phosphate-buffered saline, air dried 
and coated with $0.03 \mathrm{mg} / \mathrm{ml}$ fibronectin (Sigma Aldrich, Germany). Cell culture inserts (Millipore, Germanyl were placed in 6-well plates with 1.25 $\mathrm{ml}$ medium (MEMa with 20\% FBS) per well. The fibronectin-coated meshes were placed on the inserts and $8 \times 10^{4}$ cells in volume of $25 \mu \mathrm{l} /$ mesh were seeded on them. After $48 \mathrm{~h}$ incubation $137^{\circ} \mathrm{C}$, $5 \% \mathrm{CO}_{2}, 100 \%$ humidity), meshes were transferred to 24-well plates and incubated for up to 21 days. Culture medium (supplemented with $0.05 \mathrm{mg} / \mathrm{ml}$ ascorbic acid) was changed three times a week.

\section{Cytotoxicity testing}

After $14 \pm 2$ days, three-dimensional cultures were introduced into a dentin barrier test system as described; ${ }^{23}$ a commercially available cell culture perfusion chamber (Minucells \& Minutissue $\mathrm{GmbH}$, Bad Abbach, Germanyl made of polycarbonate with a base of $40 \times 40 \mathrm{~mm}$ and a height of $36 \mathrm{~mm}$ was modified. The three dimensional cultures placed on a dentin disc held in place by a special biocompatible stainless-steel holder, resulting in a dentin barrier test situation. The dentin disc $(500 \pm 20 \mu \mathrm{m}$ thick) was cut from a bovine incisor, etched on pulpal side with $50 \%$ citric acid for $30 \mathrm{~s}$ and autoclaved as described. ${ }^{21}$ Thus, the cell culture chamber was separated into two compartments by the dentin disc. The cell culture tissues were placed in direct contact with the etched side of the dentin disk and held in place by the stainless-steel holder. All chambers were perfused with $0.3 \mathrm{ml}$ assay medium Igrowth medium with $5.96 \mathrm{~g} / \mathrm{L}$ HEPES buffer, Merck, Germanyl per hour for $24 \mathrm{~h}$ at $37^{\circ} \mathrm{C}$. Perfusion was switched off; test materials were introduced into the upper compartment in direct contact with the "cavity" side of the dentin disc.

Cytotoxicity of test materials was recorded after the pulpal part of the in vitro pulp chamber was perfused with cell culture medium ( $2 \mathrm{ml} / \mathrm{h}$ ) for $24 \mathrm{~h}$ of incubation at $37^{\circ} \mathrm{C}$. Each material was tested 6 times; after $24 \mathrm{~h}$ incubation, vitality of the cultures was determined using the MTT assay.

Test materials

The materials are listed in Table 1. They were prepared according to the manufacturers' instructions.

Maxcem, is a two-part paste/paste dual-cure, self-etching and self-adhering resin cement. Its unique formulation combines the etchant, primer/ adhesive and resin cement into one material. Using the automix tip, the cement syringed into an insulin injector. Then applied $2 \mathrm{~mm}$ directly onto the dentin disc and light-cured (380-515 nm. LED light curing unit, Bluephase, Ivoclar Vivadent, Liechtenstein, Austrial for $20 \mathrm{~s}$ and continues to cure fully in 5 minutes.

Rely X Unicem Clicker, is a two-part paste/ paste dual cure, self-adhesive universal resin cement. The clicker used to extrude adequate amount of base paste and catalyst paste onto the mixing pad and mixed evenly for 20 seconds with a plastic spatula and put in an insulin injector. Then applied $2 \mathrm{~mm}$ directly onto the dentin disc and light-cured 1380-515 nm. LED light curing unit, Bluephase, Ivoclar Vivadent, Liechtenstein, Austrial for $20 \mathrm{~s}$ and continues to cure fully in 5 minutes.

Panavia F 2.0, is a two-part paste/paste dualcure, self-adhesive resin cement. The pastes syringed the same amount of turn and mixed for 20 seconds on the mixing pad with a plastic spatula and put in an insulin injector. Then applied $2 \mathrm{~mm}$ directly onto the dentin disc and light-cured for $20 \mathrm{~s}$ 1380-515 nm. LED light curing unit, Bluephase, Ivoclar Vivadent, Liechtenstein, Austrial and continues to cure fully in 5 minutes.

Biscem, is a two-part dual cure, self adhesive resin cement. Using the automix tip, the cement syringed into an insulin injector. Then applied directly onto the dentin disc and light-cured for 20 s (380-515 nm. LED light curing unit, Bluephase, Ivoclar Vivadent, Liechtenstein, Austrial and continues to cure fully in 6 minutes.

Bistite, is a two part paste/paste dual cure self adhesive resin cement. The syringe used to extrude adequate amount of pastes $A$ and $B$ onto the mixing pad and mixed evenly for 10 seconds with a plastic spatula and put in an insulin injector. Then applied $2 \mathrm{~mm}$ directly onto the dentin disc and light-cured for $20 \mathrm{~s}$ 1380-515 $\mathrm{nm}$. LED light curing unit, Bluephase, Ivoclar Vivadent, Liechtenstein, Austrial and continues to cure fully in 3 minutes.

A-Silicon Impression Material (President Coltene AG, Altstatten, Sweden) is used as a negative control (100\% cell viability). The pastes syringed the same amount of base and catalyst and mixed for $20 \mathrm{~s}$ on the mixing pad and put in an 
insulin injector. Then applied $2 \mathrm{~mm}$ directly onto the dentin disc and self-cured.

\section{MTT assay}

Cell viability of three-dimensional cultures was determined by enzyme activity (MTT assay). The tissues were removed from the pulp chambers, respectively, placed into 48-well plates containing $500 \mu \mathrm{l}$ of prewarmed MTT 13-14,5dimethylthiazol-2-yl)-2,5-diphenyltetrazolium bromide), (MTT, Sigma Aldrich, Germany) solution $(0.5 \mathrm{mg} / \mathrm{ml}$ in MEMa) and incubated for $2 \mathrm{~h}$ at $37^{\circ} \mathrm{C}$. Then the tissues were washed two times with phosphate-buffered saline. The blue formazan precipitate was extracted from the mitochondria using $250 \mu \mathrm{l}$ dimethyl sulfoxide on a shaker at room temperature for $30 \mathrm{~min}$.
$200 \mu \mathrm{l}$ of this solution were transferred to a $96-$ well plate and the absorption at $540 \mathrm{~nm}$ was determined spectrophotometrically ( $\mu$ Quant, Bio-Tek Instruments, Inc, Winooski, VT, USA). The mean values of control tissues (cell cultures exposed to silicone impression material) were set to represent $100 \%$ viability. Results of cytotoxicity experiments were expressed as a percentage of control tissues. Statistical analysis between control and test materials was performed applying the nonparametric Mann-Whitney U test (P>.05).

\section{RESULTS}

The results of dentin barrier test with composite resin cements are summarized in Figure 1. A vinyl poly siloxane material (President)

Table 1. Test materials, compounds and components.

\begin{tabular}{|c|c|c|c|c|}
\hline Resin Cements & $\begin{array}{l}\text { Lot } \\
\text { Number }\end{array}$ & Manufacturer & Compound & Components \\
\hline $\begin{array}{l}\text { Rely X Unicem } \\
\text { Clicker }\end{array}$ & 279830 & $\begin{array}{l}\text { 3M ESPE, } \\
\text { Seefeld, } \\
\text { Germany }\end{array}$ & $\begin{array}{l}\text { Base, } \\
\text { Catalyst }\end{array}$ & $\begin{array}{l}\text { Powder: silanized glass powder, silanized silica, } \\
\text { calcium hydroxide, substituted pyrimidine, } \\
\text { sodium persulfate } \\
\text { Liquid: methacrylated phosphoric acid esters, } \\
\text { triethylene glycol dimethacrylate, substituted } \\
\text { dimethacrylate }\end{array}$ \\
\hline Maxcem & 2712954 & $\begin{array}{l}\text { Kerr, Orange, } \\
\text { CA, USA }\end{array}$ & $\begin{array}{l}\text { Paste / } \\
\text { Paste }\end{array}$ & $\begin{array}{l}\text { Resin Matrix: Glyceroldimethacrylate dihydrogen } \\
\text { phosphate (GPDM) -self-etching/self-adhering } \\
\text { acidic monomer, Comonomers including } \\
\text { mono-, di-, and tri-functional methacrylate } \\
\text { monomers, Proprietary self-cure redox initiator, } \\
\text { Photoinitiator, Stabilizer } \\
\text { Fillers: Barium glass filler, Fluoroaluminosilicate } \\
\text { glass filler, Fumed silica }\end{array}$ \\
\hline Panavia F 2.0 & $\begin{array}{c}\text { Paste A: } \\
\text { 00185A } \\
\text { Paste B: } \\
\text { 00027A }\end{array}$ & $\begin{array}{l}\text { Kuraray, } \\
\text { Okuyama, } \\
\text { Japan }\end{array}$ & $\begin{array}{l}\text { Paste A, } \\
\text { Paste B }\end{array}$ & $\begin{array}{l}\text { Paste A: Silica, Dibenzoyl peroxide } \\
\text { Paste B: Silanated Barium Glass, silanated } \\
\text { titanium oxide, sodium fluoride, colloidal } \\
\text { silica, bisphenol A, polyethoxy dimethacrylaıte, } \\
\text { hydrophilic dimethacrylate, hydrophobic } \\
\text { dimethacrylate, N,N'-diethanol-P-toluidine, } \\
\text { sodium 2,4,6-triisopropyl benzene sulfinat }\end{array}$ \\
\hline BisCem & 700004155 & $\begin{array}{l}\text { Bisco, } \\
\text { Schaumburg, } \\
\text { IL, USA }\end{array}$ & $\begin{array}{l}\text { Base, } \\
\text { Catalyst }\end{array}$ & $\begin{array}{c}\text { Bis (Hydroxyethyl methacrylate) phosphate } \\
\text { (Base), Tetraethylene glycol dimethacrylate, } \\
\text { Dental Glass }\end{array}$ \\
\hline Bistite II DC & 50R-90C & $\begin{array}{c}\text { Tokuyama } \\
\text { Dental } \\
\text { Corporation, } \\
\text { Tokyo, Japan }\end{array}$ & $\begin{array}{l}\text { Paste A, } \\
\text { Paste B }\end{array}$ & $\begin{array}{l}\text { Filler: Silica Zirconia Matrix: Dimethacrylate, } \\
\text { MAC-10 (an adhesive promoter), initiator }\end{array}$ \\
\hline
\end{tabular}


was used as a negative control material. Biscem composite resin cement caused considerably cell damage only $52 \%$ of the cells survived when compared with cell cultures exposed to control (President) (P>.05). Exposure of the cell cultures to Rely X Unicem Clicker, Panavia F 2.0, Bistite II DC lead to $70 \%, 62 \%$ and $73 \%$ cell survival, respectively. Statistically, Rely X Unicem Clicker, Panavia F 2.0, Biscem and Bistite II DC groups were different from control material ( $P>$.05). Maxcem composite resin cement lead to $79 \%$ cell survival, and Maxcem was statistically not different from control (P>.05).

\section{DISCUSSION}

When composite resin cement materials are placed onto prepared dentin surfaces, their direct toxic effects will be most likely on the pulp cells beneath the dentin. ${ }^{10}$ According to Schmalz et $a_{1}{ }^{23,24}$ the in vitro dentin barrier test system for cytotoxicity tests might mimic a clinical situation and it is better than direct cell-material contact in vitro methods, and it has the potential to, at least partially, replace animal experimentation. This goal was achieved when a dentin disc, which functioned as a barrier, a test material, and three-dimensional cultures of pulp-derived cells were combined in a cell culture perfusion chamber. ${ }^{23,25}$ It was consistently demonstrated that dentin was an effective barrier, preventing cell damage from a great variety of materials and chemicals. For instance, cytotoxicity of dental adhesives decreased when the thickness of the dentin disc was gradually increased from 100 to $500 \mu \mathrm{m} .{ }^{26}$ This effect was apparently selective and depended on the chemical nature of the dentin contacting material. ${ }^{23,25,26}$ In the present study the composite resin cements reduced cell viability in pulp-derived three-dimensional cell cultures even though under a $500 \mu \mathrm{m}$ dentin thickness. In this paper it was demonstrated that only Maxcem composite resin cement is not cytotoxic and all other tested composite resin cements are cytotoxic on the three dimensional bovine dental papilla-derived cells when compared to control group.

Current investigations have also reported the cytotoxic effects of some resin monomers, such as BIS-GMA (Bis glycidyl methacrylate), UDMA (urethane dimethacrylate), and TEGDMA (tri ethylene glycol dimethacrylate).7,27 These resin monomers are able to deplete intracellular glutathione as well as interfere with the expression of some proteins, such as collagen I, osteonectin, and dentin sialoprotein, which play a fundamental role in the pulp repair. ${ }^{20,28,29}$

Resin monomers and other components are released from dental composite restorative materials even after polymerization. The TEGDMA and the hydrophilic monomer 2-hydroxyethyl methacrylate (HEMA) were detected among the various chemicals in hydrophilic as well as hydrophobic solvents. ${ }^{7,30,31}$ Resin monomers have been identified as cytotoxic by a variety of different methods, all indicating changes in basic cell structures such as cell membrane integrity and cell functions like enzyme activities or the synthesis of macromolecules. ${ }^{13,18,32}$ RelyX Unicem is a BIS-GMA/TEGDMA-based resin and many toxic resin monomers and chemical agents, such as TEGDMA, methacrylated phosphoric acid esters, and dimethacrylates, are incorporated in the formulation of the RelyX Unicem, it should be reasonable to expect a very high cytotoxicity of this dental cement to the culture of cells. De Mendonça et $a^{20}$ evaluted the cytotoxic effects of calcium hydroxide, Vitrebond, RelyX Luting, and RelyX Unicem cements, applied on the odontoblast like cells MDPC-23. The most intense cytotoxic effects were caused by calcium hydroxide, Vitrebond and RelyX Luting. On the other hand, RelyX Unicem caused low cytotoxic effects to the odontoblast cell line MDPC-23 but the results cannot be directly extrapolated to clinical situations in which the dental cements are applied on sound- or caries-affected dentin,

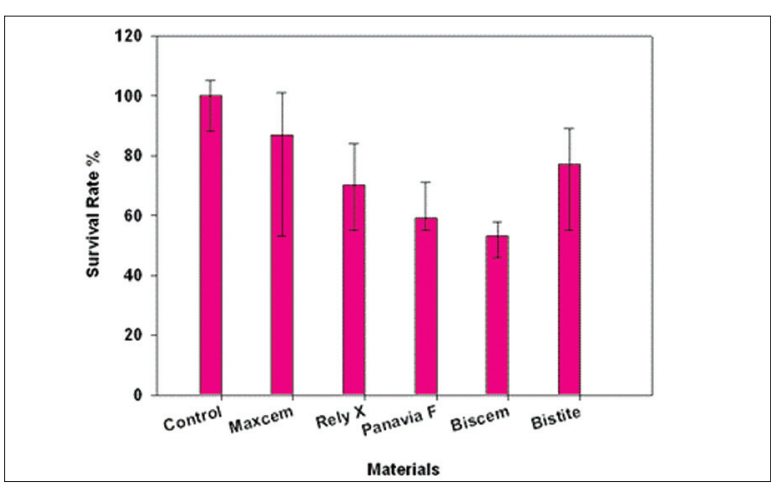

Figure 1. Cell survival of three-dimensional cultures in the dentin barrier test device after exposure to composite resin cements. Data are expressed as percentage of the negativecontrol cultures (President=silicone impression material). The indicated values are medians, $25^{\text {th }}$ and $75^{\text {th }}$ percentiles. 
and the pulp-dentin complex presents intrinsic mechanisms of defense. In the present study RelyX Unicem showed significant toxic effects on the three dimensional cell cultures.

Maxcem composite resin cement is compound of a combination of adhesive monomers, including GPDM (glyceroldimethacrylate dihydrogen phosphatel and the patented Redox Initiator System that provides an efficient curing mechanism and it was demonstrated in the present investigation that Maxcem was caused the lowest cytotoxic effects.

Biscem composite resin cement contains TEEGDMA and HEMA and in the present study the most intense cytotoxic effects were caused by Biscem for the three dimensional pulp cell cultures. Chang et $\mathrm{al}^{33}$ have shown that HEMA induces cell growth inhibition and cycle perturbation. The glutathione depletion and ROS production are key factors leading to cell apoptosis. On the other hand, we could not reach any data in the literature about cytotoxicity of TEEGDMA.

Composite resin materials may contain rather 'unknown' monomers and generally these monomers protect by patents. Patents may also hinder objective research. ${ }^{34}$ Only available composition of the resin cements tested in this study showed in Table 1. They may also contain such unknown monomers.

It was considered that such a test design was appropriate for the purpose of this study, because it was more similar to the in vivo situation, where the composite resin cements covers the dentinal walls and only indirectly interacts with the pulp, by means of the tubular fluid. In this connection, Costa et $\mathrm{al}^{10}$ investigated the pulp response following cementation of inlays using two different composite resin cements. They showed that luting cements may cause specific pulpal damage. Variolink II associated with the adhesive system Excite cause more aggressive effects to the pulp-dentin complex than Rely $X$ Unicem cement when both are used the cement inlay restorations.

\section{CONCLUSIONS}

In this study, it was concluded that the most intense cytotoxic effects were caused by Biscem> Panavia F 2.0> Rely X Unicem Clicker> Bistite II
DC. On the other hand, Maxcem caused lowest cytotoxic effects to the three dimensional cell cultures in this study.

\section{ACKNOWLEDGEMENTS}

This study was derived from PhD thesis of H. Esra Ulker. The authors would like to thank Professor Dr. Gottfried Schmalz (Regensburg University, Germanyl to supply the bovine dental papilla-derived cells to our laboratory for dentin barrier tests. This study was supported by Selcuk University BAP (06102038).

\section{REFERENCES}

1. El-Mowafy 0 . The use of resin cements in restorative dentistry to overcome retention problems. J Can Dent Assoc 2001;67:97-102.

2. Craig RG. Restorative dental materials. 10th ed. St Louis: Mosby; 1997

3. Rosenstiel SF, Land MF, Crispin BJ. Dental luting agents: A review of the current literature. J Prosthet Dent 1998;80:280301.

4. Gerzina TM, Hume WR. Diffusion of monomers from bonding resin-resin composites combination through dentine in vitro. J Dent 1996;24:125-128.

5. Geurtsen W, Spahl W, Muller K, Leyhausen G. Aqueous extracts from dentin adhesives contain cytotoxic chemical. J Biomed Mater Res Appl Biomater 1999;48:772-777.

6. Costa CAS, Hebling J, Hanks CT. Current status of pulp capping with dentin adhesive systems: a review. Dent Mater 2000;16:188-197.

7. Schweikl H, Hartmann A, Hiller KA, Spagnuolo G, Bolay C, Brockhoff G, et al. Inhibition of TEGDMA and HEMA-induced genotoxicity and cell cycle arrest by $\mathrm{N}$-acetylcysteine. Dent Mater 2007;23:688-695.

8. Demirci M, Hiller KA, Bosl C, Galler K, Schmalz G, Schweikl $H$. The induction of oxidative stress, cytotoxicity, and genotoxicity by dental adhesives. Dent Mater 2008; 24:362371.

9. Costa CAS, Nascimento ABL, Teixeira HM. Response of human pulps following acid conditioning and application of a bonding agent in deep cavities. Dent Mater 2002;18:543551.

10. Costa CAS, Hebling J, Randall RC. Human pulp response to resin cements used to bond inlay restorations. Dent Mater 2006;22:954-962.

11. Moszner N, Ulrich S. New developments of polymeric dental composites. Prog Polym Sci 2001;26:535-576. 
12. Sideridou ID, Achilias DS Elution study of unreacted bisGMA. TEGDMA, UDMA, and bis-EMA from light-cured dental resins and resin composites using HPLC. J Biomed Mater Res B Appl Biomater 2005;74:617-626.

13. Yoshii E. Cytotoxic effects of acrylates and methacrylates: relationships of monomer structures and cytotoxicity. $J$ Biomed Mater Res 1997;37:517-524.

14. Geurtsen W, Lehmann F, Spahl W, Leyhausen G. Cytotoxicity of 35 dental resin composite monomers/additives in permanent 3 T3 and three human primary fibroblast cultures. J Biomed Mater Res 1998;41:474-480.

15. Altintas $\mathrm{SH}$, Usumez A. Evaluation of monomer leaching from a dual cured resin cement. J Biomed Mater Res Part B: Appl Biomater 2008;86B:523-529.

16. Ferracane JL. Elution of leachable components from composites. J Oral Rehabil 1994;21:441-452

17. Goldberg M. In vitro and in vivo studies on the toxicity of dental resin components: a review. Clin Oral Invest $2008 ; 12: 1-8$

18. Hanks CT, Strawn SE, Wataha JC, Craig RG. Cytotoxic effects of resin components on cultured mammalian fibroblasts. J Dent Res 1991;70:1450-1455.

19. Jontell M, Hanks CT, Bratell JT, Bergenholtz G. Effects of unpolymerized resin components on the function of accessory cells derived from the rat incisor pulp. $J$ Dent Res 1995;74:1162-1167.

20. de Mendonça AA, Souza PP, Costa CA. Cytotoxic effects of hard-setting cements applied on the odontoblast cell line MDPC-23. Oral Surg Oral Med Oral Pathol Oral Radiol Endod 2007;104:102-108.

21. Schmalz G, Garhammer P. Schweikl H. A commercially available cell culture device modified for dentin barrier tests. J Endod 1996;22:249-252.

22. Thonemann B, Schmalz G. Bovine dental papilla-derived cells immortalized with HPV 18 E6/E7. Eur J Oral Sci 2000;108:432-441.

23. Schmalz G, Schuster U, Nützel K, Schweikl H. An in vitro pulp chamber with three-dimensional cell cultures. $J$ Endod 1999;25:24-29.

24. Schmalz G, Schuster U, Thonemann B, Barth M, Esterbauer S. Dentin barrier test with transfected bovine pulp-derived cells. J Endod 2001;2:96-102.

25. Schuster U, Schmalz G, Thonemann B, Mendel N, Metzl C. Cytotoxicity testing with three-dimensional cultures of transfected pulp-derived cells. J Endod 2001;27:259-265.

26. Galler K, Hiller KA, Ettl T, Schmalz G. Selective influence of dentin thickness upon cytotoxicity of dentin contacting materials. J Endod 2005;31:396-399.
27. Schweikl H, Spagnuolo G, Schmalz G. Genetic and cellular toxicology of dental resin monomers. $J$ Dent Res 2006;85:870-877.

28. Engelmann J, Leyhausen G, Leibfritz D, Geurtsen W. Effect of TEGDMA on the intracellular glutathione concentration of human gingival fibroblasts. J Biomed Mater Res 2002;63:746751.

29. Engelmann J, Janke V, Volk J, Leyhausen G, von Neuhoff N, Schlegelberger B, Geurtsen W. Effects of BisGMA on glutathione metabolism and apoptosis in human gingival fibroblasts in vitro. Biomaterials 2004;25:4573-4580.

30. Santerre JP, Shajii L, Leung BW. Relation of dental composite formulations to their degradation and the release of hydrolyzed polymeric-resin-derived products. Crit Rev Oral Biol Med 2001;12:136-151.

31. Michelsen VB, Lygre $H$, Skalevik R, Tveit AB, Solheim E. Identification of organic eluates from four polymer-based dental filling materials. Eur J Oral Sci 2003;111:263-271.

32. Thonemann B, Schmalz G, Hiller K-A, Schweikl H. Responses of L929 mouse fibroblasts, primary and immortalized dental papilla-derived cell lines to dental resin components. Dent Mater 2002;18:318-323.

33. Chang HH, Guo MK, Kasten FH, Chang MC, Huang GF Wang YL, Wang RS, Jeng JH. Stimulation of glutathione depletion, ROS production and cell cycle arrest of dental pulp cells and gingival epithelial cells by HEMA. Biomaterials 2005;26:745-753.

34. Van Landuyt KL, Snauwaert J, De Munck J, Peumans M, Yoshida Y, Poitevin A, Coutinho E, Suzuki K, Lambrechts P, Van Meerbeek B. Systematic review of the chemical composition of contemporary dental adhesives. Biomaterials 2007;28:3757-3785 